\title{
LOGISTICS COMPETENCE AS A COMPONENT OF THE PROFESSIONAL COMPETENCE OF A FUTURE OFFICER
}

\author{
Yurii KORNIICHUK \\ korniy.yg@gmail.com \\ https://orcid.org/0000-0002-0699-3811 \\ Yevhen STAROKON \\ ksn_zvir@ukr.net \\ https://orcid.org/0000-0001-8833-0351 \\ Oleksandr SHKATULA \\ shkatula_a_p@ukr.net \\ https://orcid.org/0000-0003-0119-6167 \\ Zhytomyr Military Institute
}

\begin{abstract}
The paper explores the problem of developing logistics competence as a component of military professional competences of future professionals of the Armed Forces of Ukraine. The main purpose of the study is to investigate the current status of the process of developing logistics competence. In this paper, we clarify the scope of the concept of logistics competence. Specifically, we ascertain the dependence of logistics efficiency on logistics competence and outline the current status of the process of developing future officers' logistics competence.
\end{abstract}

Keywords: automotive equipment, Armed Forces of Ukraine, logistics, logistics competence

\section{INTRODUCTION}

Military aggression in modern societies has actualized and accelerated the development of logistics as a new scientific and practical direction for Ukraine, which has already become an efficient tool for businessmen and military professionals in most developed countries. The increased attention to logistics is associated with the existing possibilities to improve the efficiency of economic systems that use the logistics approach to managing material resources. The Strategic Defense Bulletin of Ukraine (White Book 2018) outlines the results of the work of the Reform Committee of the Ministry of Defense of Ukraine and the Armed Forces of Ukraine, including "the creation of a single efficient logistics system for defense forces in accordance with NATO guidelines, standards, and instructions; as well as logistical support of the defense forces, material and technical stocks, which are maintained in accordance with the norms that ensure the implementation of tasks on purpose in peacetime and wartime ("special period")" [5]. However, logistics as a new scientific direction for the Armed 
Forces and as a practical technique for providing troops, which combines both rear and technical support, needs further development and harmonization with the logistics approaches used by Ukraine's partners - NATO member countries.

At the same time, logistics and military logistics in particular, is based not only on clear algorithms and rules of operation, it also requires the leadership contribution of the personnel who will be able to work according to established rules and procedures. That is why the purpose of this paper is to study the logistics competence as a necessary prerequisite for effective professional activity of future officers.

\section{LOGISTICS COMPETENCE: THE ESSENCE OF THE CONCEPT}

As a rule, the concept of logistics competence is used in assessing the effectiveness of logistics systems, and etymologically consists of two separate concepts: logistics and competence.

This concept is usually interpreted in two ways: firstly, military logistics is a field of military science, which is associated with the movement and supply of the army; secondly, philosophical logistics, or mathematical logic, is a subfield of philosophy associated with the use of mathematical apparatus to prove deductive statements $[11,13]$.

Furthermore, the concept of logistics is broadly defined as a combination of principles and approaches to the organization and management of various areas of economic activities (military and civilian) at all its macro- and micro-levels, as well as their phases and stages.

I. Galperin in his dictionary defines the concept of "logistics" as: a) rear and supply; b) materiel support; c) rear services. An American expert in systems analysis O. Morgenstern points out the similarity between the management of troops and material, resources and notes the possibility of using the principles of military logistics in the economy $[11,13]$. R. Ballou defines logistics as the doctrine of planning, organizing, and controlling all activities regarding the movement and storage, which ensure the passage of raw material flow from the point of acquisition to the point of consumption [1, p. 12]. According to R. Miles, logistics is a process of managing the movement and storage of raw materials and finished products from the moment of paying money to suppliers till the moment of receiving money from consumers [2]. Such researchers as A. Gadzhinsky, V. Zdanevich, A. Kalchenko, L. Mitina, and others understand logistics as the interdisciplinary research area, which is naturally associated with the search for new reserves to improve the efficiency of material flows [13], integration of transportation processes and production, which consists of loading and unloading operations, as well as the storage and transportation of goods and the necessary information support $[9, \mathrm{p} .7]$. 
Thus, the concept of logistics in the Armed Forces should be understood as the management of the process of rational troop management, aimed at meeting the unit support requirements.

In turn, the concept of competence is now widely used in scientific discourse. This fairly new concept first appeared in the second half of the twentieth century as a concept that defined the achievement of the appropriate education level or educational outcome. Now it is the focus of urgent global attention, as it opens up qualitatively new opportunities in understanding the mission of education and the results of educational activities. The analysis of scientific papers shows that F. Weinert, R. Kegan, J. Consant, J. Kullahan, T. Oats, J. Perre, D. Reichen, L. Salganik, G. Hallash, and others dedicated their works to the study of this concept. Additionally, such Ukrainian researchers as O. Antonova, N. Bibik, S. Vitvytska, N. Volkova, M. Golovan, O. Dubasenyuk, I. Zymnya, I. Zyazyun, V. Kalney, O. Pometun, H. Selevko, F. Sharipov were engaged in the development of the scope of this concept.

In Ukrainian pedagogy, the first attempts to define the meaning of the term "competence" belong to O. Ovcharuk and B. Chyzhevsky. Their works outline the main competencies in the education of European countries [11, 18]. According to O. Pometun, it is necessary to take into account that competence is the result of acquiring competencies, and therefore it should be perceived as an objective category that formalizes a socially recognized result [12]. N. Bibik defines competence as an element of the content structure of education, which is based on modern standards on the branch-wise principle and derives a universal level, which is an integrated form represents the learning outcomes [4]. O. Khutorskyi defines the concept of competence as a set of interrelated personality traits (knowledge, skills, abilities, methods that are set in relation to a certain range of subjects and processes necessary for productive activities in them) [17]. This concept is based on the idea of forming a personality - an employee who not only has the necessary knowledge, but also is able to act accordingly in different situations, applying knowledge and being responsible for their activities [16].

Currently, experts identify three main components of the competence structure knowledge, skills and values (qualities) of personality. Thus, I. Zymnya defines competence as an actualized, integrative, knowledge-based, intellectually and socio-culturally determined personal quality, which is manifested in human activity, behavior, as well as in the interaction with other people in solving various problems [8]. The researcher considers the following distinguishing features of a competence: the readiness to show the competence (motive); the knowledge of the competence content (intelligence); the experience of the competence performance in various standard and non-standard situations (behavior); the attitude to the competence content and the objects of its application (values); the emotional and volitional regulation of the process and the result of the competence manifestation [7]. 
In Ukrainian higher education, as well as in military education in particular, a competence is understood as the interpretation defined in paragraph 13 of Article 1 of the Law On Higher Education of Ukraine: the ability of a person to successfully socialize, to learn, and to pursue professional activities, and which is based on a dynamic combination of knowledge, skills, abilities, ways of thinking, views, values, and other personal qualities [14].

Thus, we consider logistical competence of a military professional as the ability of a person to successfully manage the process of rational logistics and information support of a unit, aimed at meeting its needs based on the available dynamic combination of knowledge, skills, as well as ways of thinking, views, values, and personal qualities.

\section{LOGISTICS COMPETENCE AS A FACTOR OF LOGISTICS EFFICIENCY}

Every two years, the World Bank evaluates 160 countries around the world and develops the Logistics Performance Index (LPI), which is an interactive benchmarking tool designed to help countries identify existing challenges and opportunities in their logistics systems. At the same time, it indicates the rating of the country's logistics efficiency.

According to the World Bank data, over the past two years, Ukraine has risen in the ranking by 14 positions - from 80 to 66th place, improving the overall score from 2.74 to 2.83. Such countries as Poland, Hungary, Romania, and Slovakia precede Ukraine ranking with numbers 28, 31, 48, 53 respectively. Kazakhstan (71), Russia (75), Belarus (103) come after Ukraine. The last place (160) and the worst indicator (1.95) belong to Afghanistan. The best indicator is 4.20, which pertains to Germany, followed by Sweden, Belgium, Austria and Japan [10].

The rating methodology considers six main criteria that influence and determine the country's logistics success: the customs legislation; the state, development, and operation of infrastructure; the availability and share of international deliveries; the ability to track products; timely delivery and logistics competence of staff. The following criteria determined the ranking of Ukraine: custom charges -2.49 , infrastructure -2.22 , international shipments -2.83 , tracking and tracing -3.11 , timeliness of delivery -3.42 , logistics competence -2.84 [10]. These indicators are integrated and determined by the legislative, infrastructural and technical level of the development of Ukraine, and depend on the external course, internal stability of the economy, political developments, etc. However, the last of these indicators, that is logistics competence, is an indicator of the level of staff proficiency and professionalism. The analysis of LPI and logistics competence in comparison with the general place of Ukraine in the world ranking of logistics (Table 1) allows understanding that logistics competence directly affects the efficiency of logistics systems, 
and therefore, to some extent, can reduce the impact of socio-political and economic negative factors (Fig. 1).

According to another study of the World Bank, the availability of competencies, skills and training in logistics is be indicative of the fact that logistics is an area that requires skilled professionals. However, as a rule, the employment in the field of logistics has a lower status and is paid less than activities in other areas, and therefore is less attractive and prestigious. With a sufficient number of personnel, the lack of professional training for a career in logistics system leads to difficulties in retraining. Performing logistics job duties often requires improving one's professional skills in new information technologies. The personnel problem for the efficiency of logistics in Ukraine is not exclusive. However, currently there is inadequate availability of material resources, funding, as well as shortages and randomness of working hours of staff to upgrade their skills in logistics [15].

Table 1. Analysis of criteria for the development of logistics in Ukraine

\begin{tabular}{|c|c|c|c|}
\hline Year & LPI Rank & Logistics competence & LPI Score \\
\hline 2007 & 73 & 2,41 & 2,55 \\
\hline 2010 & 102 & 2,59 & 2,57 \\
\hline 2012 & 66 & 2,85 & 2,85 \\
\hline 2014 & 61 & 2,84 & 2,98 \\
\hline 2016 & 80 & 2,74 & 2,55 \\
\hline 2018 & 66 & 2,84 & 2,83 \\
\hline
\end{tabular}

Source: https://lpi.worldbank.org/international/global/2018

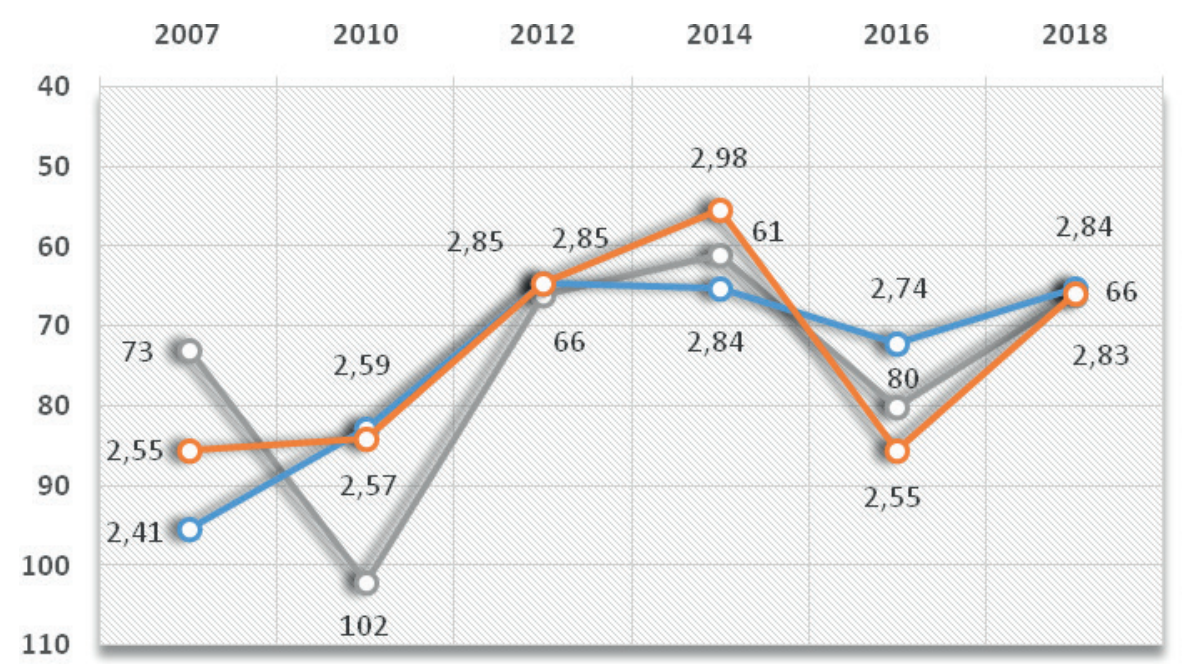

Fig.1. Ratio of logistics competence and LPI score of Ukraine Source: Adapted from: https://lpi.worldbank.org/international/global/2018 
In order to address the issue of training highly qualified specialists in logistics, the efforts of logistics departments, as well as professionals, training service providers, and officials in this area should be coordinated. Additionally, significant results should be expected when combining assistance, regulation, consulting, financing, and planning in the field of staff logistics competence development.

Considering the fact that Ukraine ranked $6^{\text {th }}$ out of 160 countries in the ranking of logistics efficiency in 2018, it should be noted that there is a need to improve the skills of Ukrainian logistics specialists. Given the above, the higher education institutions in Ukraine should first of all provide an appropriate level of training in the field of logistics and transport. The accomplishment of this task has a number of challenges. There is, for example, a wide range of works and tasks of logistics activities; a large number of logistics tasks are within one's own professional activities; many tasks are beyond the scope of one profession; determining the necessary logistics skills or requirements for them are often problematic; in general, a small number of unified training requirements for logistics competence development have been outlined till now; most curricula do not have the necessary flexibility, they quickly lose their relevance, in particular, in vocational education; additionally, there are difficulties in planning training resources and selecting future professionals.

Thus, the availability of well-trained staff is a necessary condition for improving the efficiency of logistics services, as well as the level of work carried out within activities at enterprises and institutions.

\section{MILITARY AUTOMOTIVE EQUIPMENT AS AN ELEMENT OF MILITARY LOGISTICS}

The modern Armed Forces of Ukraine are characterized by the development in the direction of increasing mobility, autonomy and the speed of response to contemporary risks and challenges, as it is stated in the Vision of the General Staff of the Armed Forces of Ukraine (on army development for the next 10 years) with the priority of the advancement of the Land Forces as a leading component. Thus, the evolvement of the Logistics Forces is going to be aimed at the upkeep of armament and military equipment, material assets and supplying by them forces (troops) of all defence forces components, as well as creating an effective infrastructural support system of forces (troops), by identifying the needs, as well as planning and organization of logistics support to troops [6].

The Vision emphasizes that "Combat units should not be burdened with stockpiles, armaments and equipment should have enough endurance. Troops must be able to move in a threatening direction in a short time and complete the assigned task, knowing that they will be provided with everything they need. They should not be in "deaf" defence, but should be able to move quickly and appear in areas 
where the enemy does not expect them. Units and troops of all levels must be able to operate independently, in a whole isolation and also in small formations that are easy to be moved by air." [6]. It is natural that the autonomy, mobility, and speed of troops depend on vehicles that meet all requirements and are able to satisfy the needs of military personnel.

Some samples of the wheeled vehicle fleet (most of which were developed during the Soviet period) can be found on the official website of the Ministry of Defense of Ukraine [3]. These are UAZ-469, 3151, GAZ-66, ZIL-131, URAL-4320, KAMAZ-4310, KRAZ-250 (257, 260), UAZ-452A, MAZ-537, MAZ-543, ZIL-135LM. Most of this equipment, despite some technical modernization, is obsolete and in fact unable to perform the current tasks of the Armed Forces of Ukraine. This is the reason why new military equipment has recently been intensively developed at state and private enterprises. Among them there are a lot of samples of mobile and fast automotive equipment (Table 3).

Table 3. New samples of automotive equipment of the Armed Forces of Ukraine

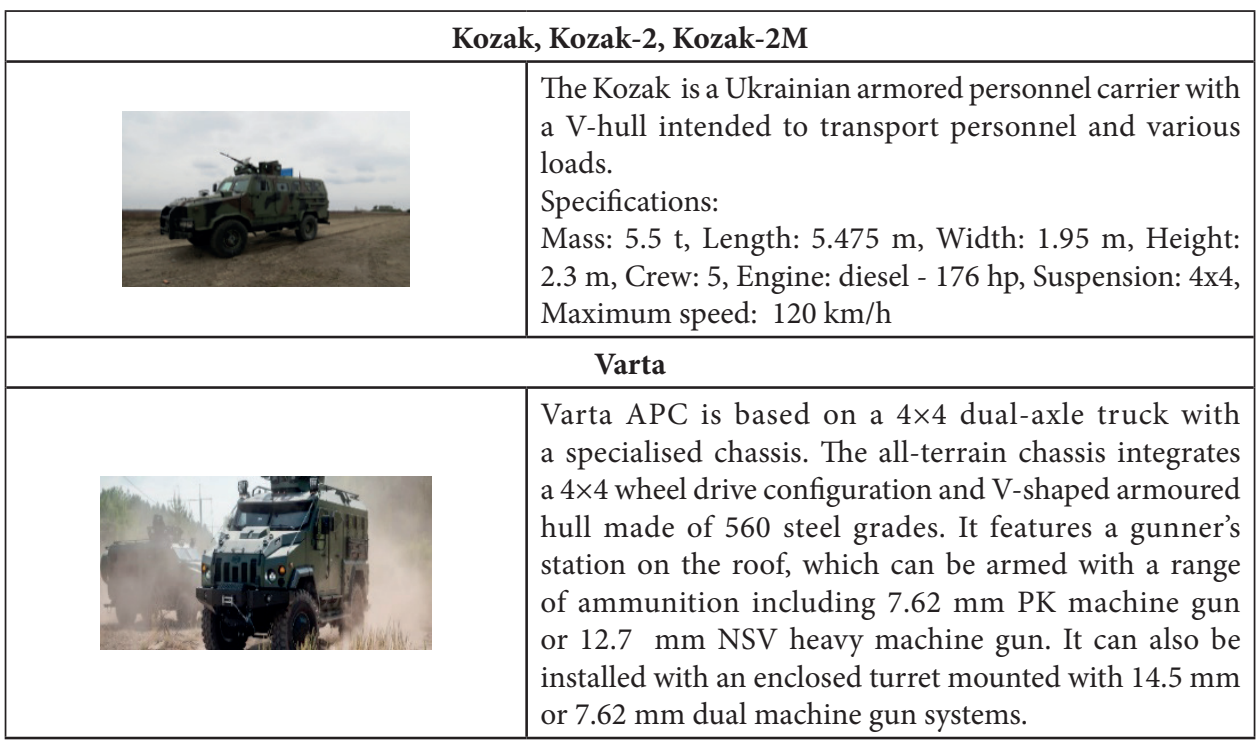




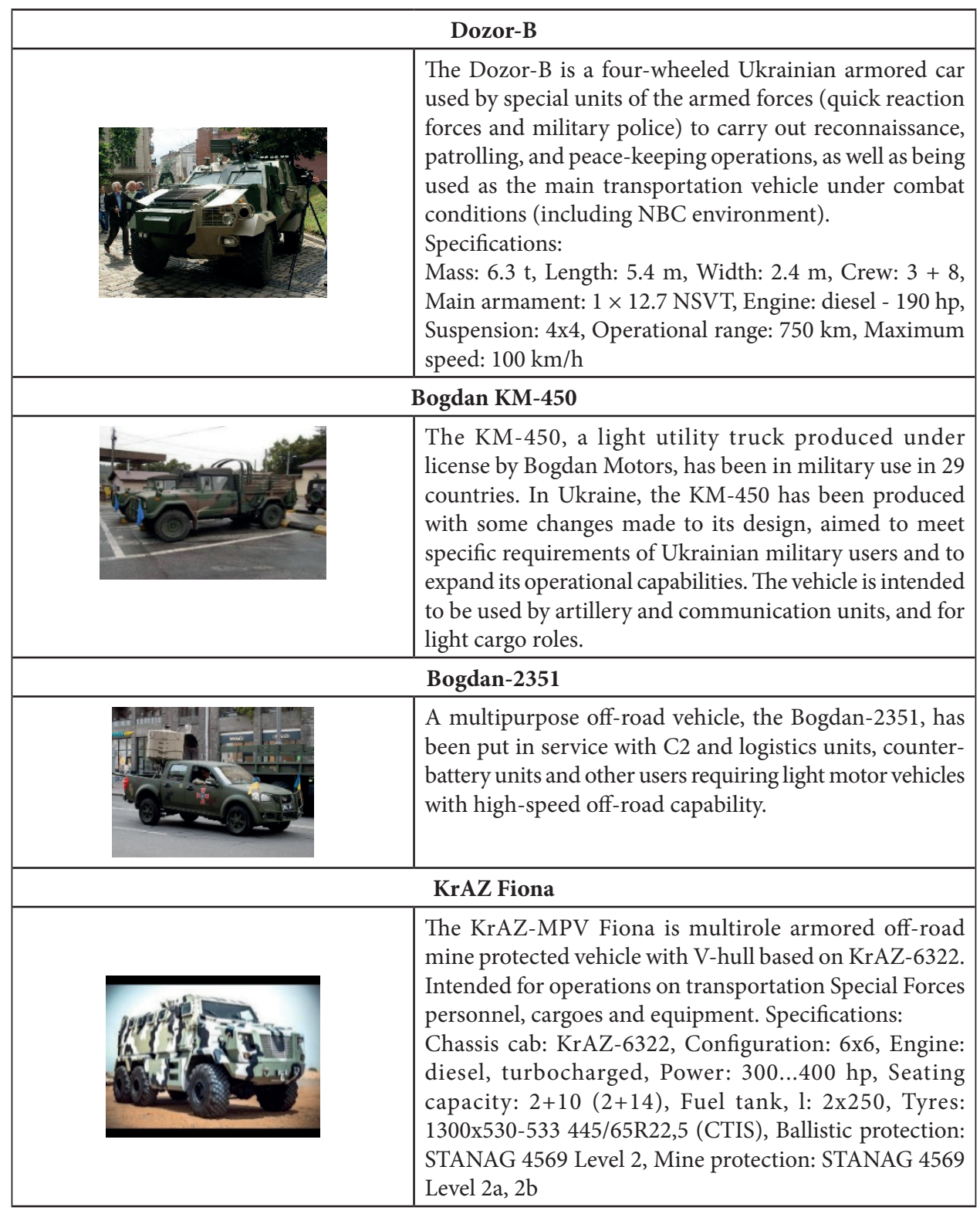




\begin{tabular}{|c|c|}
\hline \multicolumn{2}{|r|}{ KrAZ -Cougar } \\
\hline 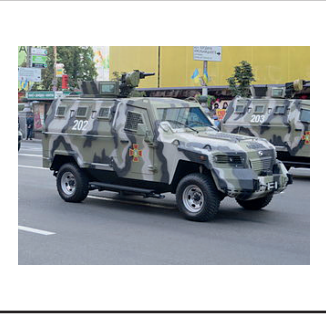 & $\begin{array}{l}\text { The KrAZ-Cougar is highly mobile armored vehicle } \\
\text { designed for carrying and protecting personnel. } \\
\text { Specifications: } \\
\text { Configuration: } 4 x 4 \text {, Truck gross weight: } 5900 \mathrm{~kg} \text {, Engine } \\
\text { Type: } 4.0 \mathrm{~L} \text { gasoline, Power: } 218 \text { hp, Tyres: } 225 / 70 \mathrm{R} 19,5 \\
\text { (RunFlat), Gearbox: manual ( } 5 \text {-speed), Max speed: } \\
105 \mathrm{~km} / \mathrm{h} \text {, Seating capacity: } 2 \text { crewmembers + } 6 \text { seats, } \\
\text { Protection: CEN level BR6, Floor: } 2 x D M 51 \text { grenades }\end{array}$ \\
\hline \multicolumn{2}{|r|}{ KrAZ-Hurricane } \\
\hline & $\begin{array}{l}\text { The KrAZ-Hurricane multirole armored vehicle is } \\
\text { designed for various combat missions. Specifications: } \\
\text { Chassis cab: KrAZ-7634HE, Configuration: } 8 \times 8 \text {, Truck } \\
\text { curb weight: } 24000 \mathrm{~kg} \text {, Load carrying capacity: } 5000 \\
\text { kg, Engine: diesel, turbocharged, Power: } 350 . .450 \mathrm{hp} \text {, } \\
\text { Gearbox: automatic, } 6 \text {-speed, Seating capacity: } 2+10 \text {, Fuel } \\
\text { tank, 1: } 2 \times 250 \text {, Protection level; STANAG } 4569 \text { Level } 4\end{array}$ \\
\hline \multicolumn{2}{|c|}{ Refrigerated van based on the KrAZ-6511H4 } \\
\hline tis & $\begin{array}{l}\text { Refrigerated van based on the KrAZ-6511H4 chassis } \\
\text { is designed for transportation of goods requiring the } \\
\text { maintenance of a certain temperature, in particular food. } \\
\text { Van body is provided with a refrigeration unit; interior } \\
\text { lighting; electrical system; separated doors and extending } \\
\text { ladders for external loading and unloading of food. } \\
\text { Specifications: } \\
\text { Basic chassis cab: KrAZ-6511H4, Configuration: } 6 \times 4 \text {, Chassis } \\
\text { truck gross weight: } 33200 \mathrm{~kg} \text {, Load carrying capacity: } 23400 \\
\text { kg, Engine: diesel, turbocharged, Power, h.p.: } 300 . . .400 \text {, } \\
\text { Van volume: } 45,7 \mathrm{~m}^{3} \text {, Interior dimensions of the van, mm: } \\
\text { 7650x } 2468 \times 2420 \text {, Fuel tank, 1: } 250 \text {, Tyres: } 11.00 \mathrm{R} 20\end{array}$ \\
\hline
\end{tabular}

Source: Prepared by the authors

Furthermore, the main feature of the latest pieces of automotive equipment is that all manufacturers offer a modular principle of construction, which allows producing equipment for different purposes on one chassis. These can be: a personnel carrier; a tactical vehicle; a command-and-control vehicle; an ambulance vehicle; and an explosive ordnance disposal vehicle. Such equipment is also dual-purpose, as it can be used with minor improvements in civilian life (Fig. 2). 


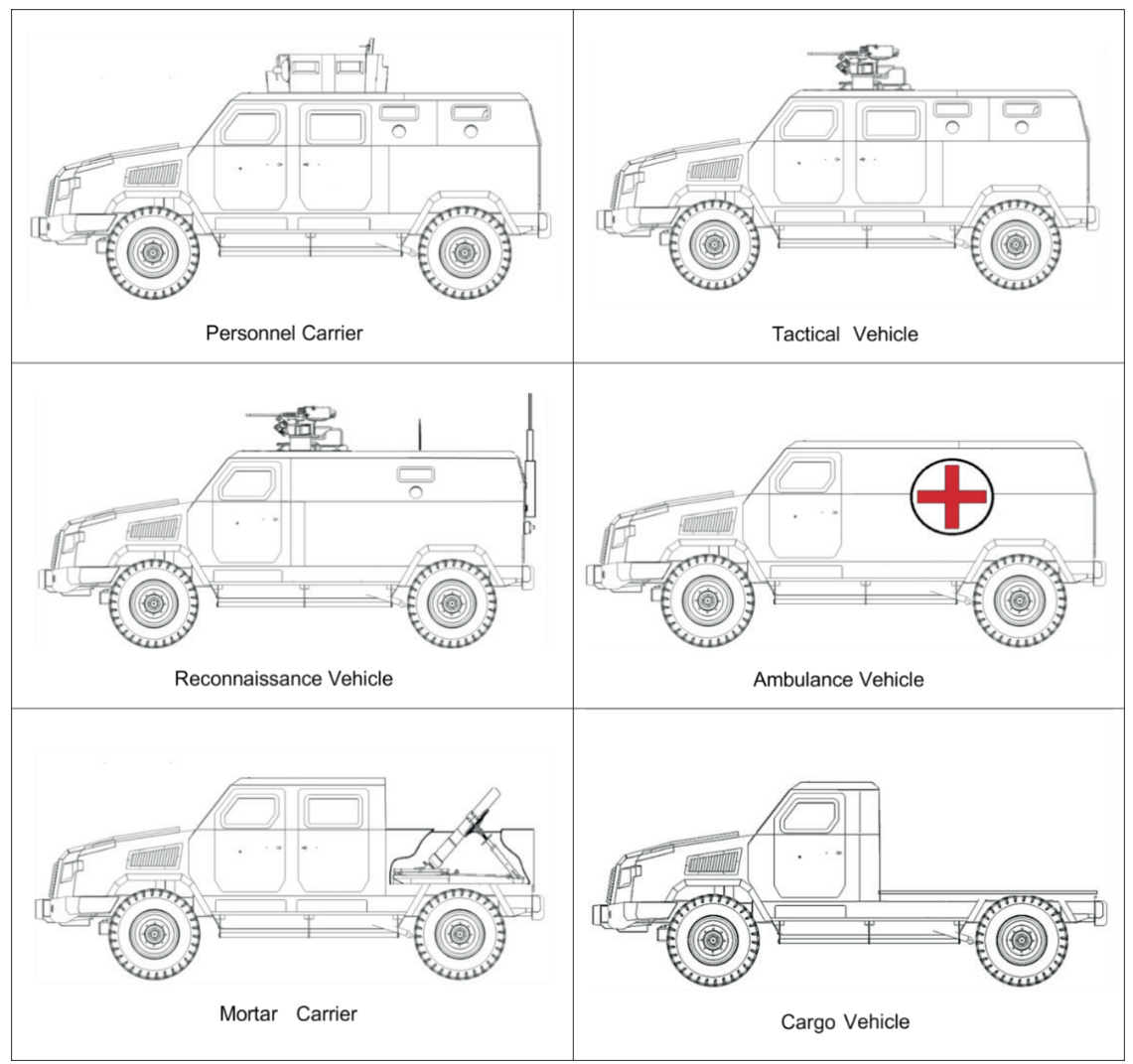

Fig. 2. Main basic modifications of new automotive equipment Source: Adapted from: http://ldc.org.ua/en/products/transport-spets-naznacheniya-npo/

\section{CURRENT STATUS OF MILITARY STUDENTS' LOGISTICS COMPETENCE DEVELOPMENT}

The rapid influx of new military equipment over the past five years, which can be used in a variety of military and military-economic activities, leads to a situation in which its effective use in the interests of units and the tasks obtained, as well as its successful logistics support is constrained by insufficient commanders' awareness of certain combat and technical capabilities and peculiarities of logistics support, that is insufficiently formed logistics competence.

Training programs for military specialists provide for the formation of a set of military-professional competencies, which in their dynamic integrative combination form the logistics competence of a military specialist. Some of them are relevant to the formation of logistics competence. Their list should include: 
- the ability to manage and lead a platoon (company) during all types of combat, in travel or on the spot, and to organize all types of combat support;

- the ability to drive category $\mathrm{C}$ vehicles under different road conditions; to comply with the requirements of traffic rules, rules of cargo and personnel transportation; to ensure the proper serviceability status of motor vehicles;

- the ability to organize daily activities in the unit; to plan measures of combat and mobilization readiness, state secret protection, management of company administration and services; as well as to monitor their implementation;

- the ability to organize and carry out engineering support measures in units, and to use engineer equipment.

Based on the definition of logistics, the closest to the content of logistics competence is the result of training, which is an integrated ability of a military specialist to drive category $\mathrm{C}$ vehicles with competence under all types of road and weather conditions, day and night, as part of the column; to utilize performance capabilities of automotive base chassis in accordance with loading capacity, speed, maneuverability, off-road capability and haulage capacity; to prepare vehicles for use; to perform daily maintenance and make out travel documentation; to carry out control of vehicle condition and completeness; to deal with enroute breakdowns; to carry out maintenance operations; to perform a set of works on maintenance of vehicle chassis in storage; to ensure the established internal order of maintenance and storage at vehicle pools of units; to organize and conduct training in driving automotive base chassis as well as mechanical training; to instruct drivers and vehicle commanders.

The study of the content of training programs for future officers of the Armed Forces of Ukraine enable us to claim that there is the time allowed for developing a list of logistics competencies of future military professionals. In order to get feedback from the cadets about their awareness of the use of new samples of automotive equipment in their future professional activities, we conducted a survey of the graduates of 2020 . The sample group consisted of $86 \%$ of the graduation course.

Our study was based on the following basic research questions:

- the cadets' understanding of the essence and content of the concept of military logistics;

- the ideas about the alignment of functions and their role in the logistics process;

- the sources of information on new samples of military vehicles;

- the level of awareness of tactical and technical characteristics and logistical capabilities of new samples of automotive equipment;

- the confidence in their ability to organize logistics in the unit.

The analysis of the obtained results allowed us to make the following conclusions: 
The majority of respondents associate logistics with the provision of troops with material and weapons $-43.3 \%$; transfer of goods, materials, substances, and information $-36.7 \%$.

1) $20 \%$ of respondents expressed the opinion that logistics is within the competence of the unit commander, $30 \%$ - within the competence of logistics services, and $25.1 \%$ - within the competence of special structures and officials.

2) At the same time, $38.3 \%$ of respondents consider military logistics to be their professional issues, $24.2 \%$ - their job responsibilities.

3) Among the model range of new automotive equipment the most mentioned were the Kozak - 58\%, the Spartan - 54\%, the Verba - 29\%, the Otaman $28 \%$, and the most famous manufacturer - Kremenchug Automobile Plant (KrAZ) $-88 \%$.

4) In the survey, $44.2 \%$ of cadets indicated that they know the tactical and technical characteristics of vehicles, and $23.3 \%$ showed readiness to study them if necessary.

5) The main sources of information on new automotive equipment were the following: Internet $-44.4 \%$, television $-11.7 \%$, training classes $-30.8 \%$, print media $-9.2 \%$, personal experience $-13.4 \%$, and others $-13.3 \%$ (Fig. 3 ).

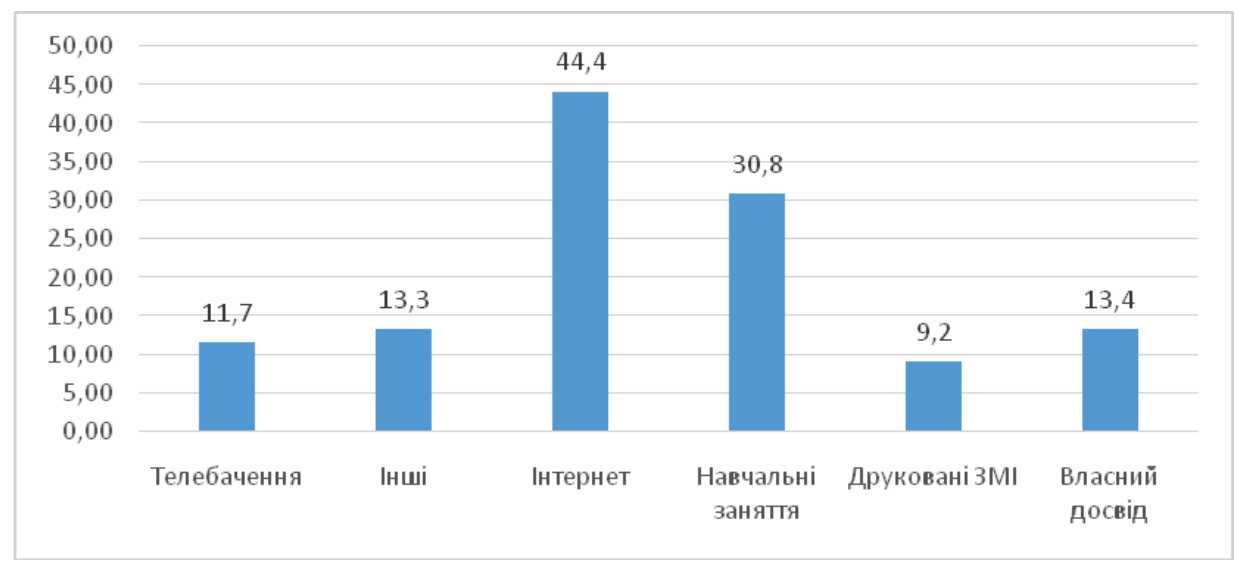

Fig. 3. Sources of information about new automotive equipment Source: Drawn by the authors

6. The self-assessment of the ability to organize military logistic activities in subordinate units indicates that the cadets highly praise their potential in this area. In general, more than $70 \%$ of them rated it at $60 \%$ and above (Fig. 4). 


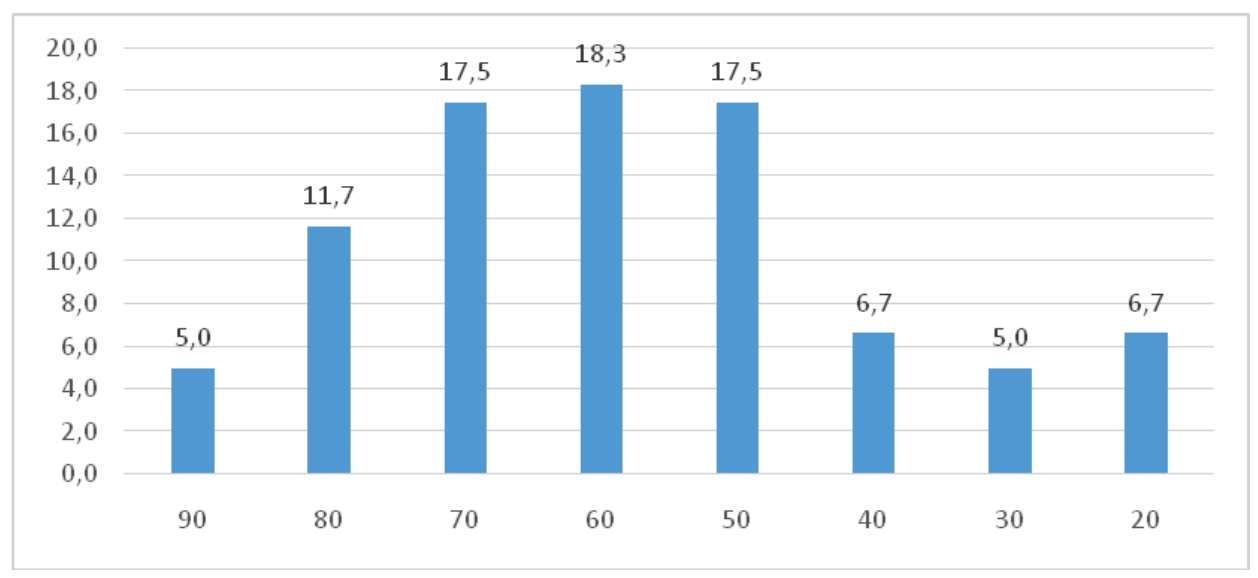

Fig. 4. Self-assessment of the ability to organize military logistic activities in units Source: Drawn by the authors

Almost half of the respondents (48.4\%) indicated the need for additional knowledge on military logistics.

The main reasons for the need to get additional knowledge on military logistics were as follows: future service in the Armed Forces $-22.5 \%$, lack of personal confidence $-13.3 \%$; transition to NATO standards $-3.3 \%$, and the desire for self-improvement - $13.3 \%$ (Fig. 5).

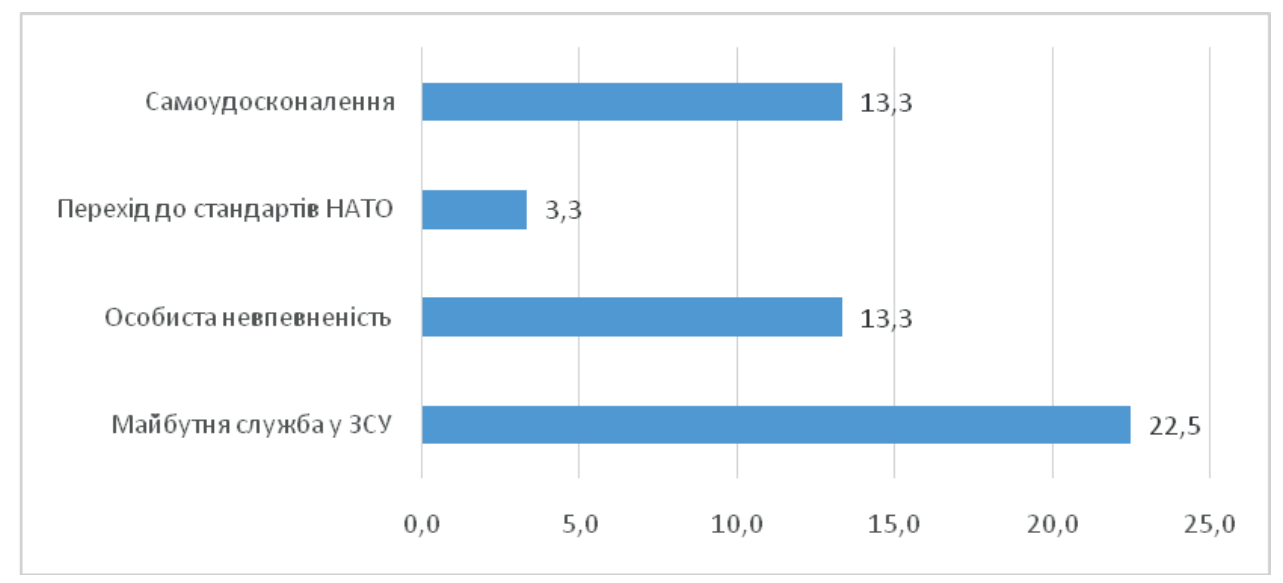

Fig. 5. Main reasons for the need to get additional knowledge on military logistics Source: Drawn by the authors 


\section{CONCLUSIONS}

Thus, the logistics system, which is built in the military in its content is a military-economic phenomenon, and depends not only on the logistics of troops, technological capabilities of state-owned and commercial enterprises of the Ukrainian military-industrial complex, but also on the logistics competence of future officers. The existing system of logistics competence development, as the ability of a person to successfully manage the process of rational logistics and information support of the unit, aimed at meeting its needs based on the available dynamic combination of knowledge, skills, ways of thinking, views, values and personal qualities, is unable to provide its required level. This requires more active improvement of organizational and managerial measures, in particular, such as the humanization and humanitarization of the education; introducing variable courses in military logistics into the curricula of higher military education institutions; teaching military logistics within the integrated courses; using distance learning technologies and self-education with the subsequent certification of the received competences; evaluating and developing future officers' qualities, which are professionally important for the sphere of military-economic logistics.

\section{REFERENCES}

[1] Headquarters Department of Army. (1996). Army Training and Evaluation Program No. 17-237-10-MTP: Mission Training Plan for the Tank Platoon. Washington.

[2] Magee, J.F., Capacino, W.F., Copacino, W.C., \& Rosenfield, D. B. (1985). Modern logistics management: Integrating marketing, manufacturing and physical distribution (Vol. 22), 1-29. John Wiley \& Sons.

[3] The Ministry of Defense of Ukraine. (2020). Avtomobilna tekhnika. http://www. mil.gov.ua/ministry/ozbroennya-ta-texnika/suxoputnix-vijsk/avtomobilna-texnika. html (04.02.2020).

[4] Bıвıк, N. (2005). Kompetentnistnyi pidkhid: refleksyvnyi analiz zastosuvannia. Osnovna shkola. 3-4.

[5] The Ministry of Defense of Ukraine. (2020). Bila knyha - 2018. Zbroini Syly Ukrainy. http://www.mil.gov.ua/content/files/whitebook/WB-2018.pdf (03.02.2020).

[6] The Ministry of Defense of Ukraine. (2020). Viziia Heneralnoho shtabu ZS Ukrainy shchodo rozvytku Zbroinykh Syl Ukrainy na naiblyzhchi 10 rokiv. http://www.mil.gov. ua/news/2020/01/11/viziya-generalnogo-shtabu-zs-ukraini-shhodo -rozvitku-zbrojnihsil-ukraini-na-najblizhchi-10-rokiv.html (09.03.2020).

[7] Zymniaia, Y. A. (2009). Kliuchevue kompetentsyy - novaia paradyhma rezultata obrazovanyia. Vysshee obrazovanye sehodnia, 2, 7-14.

[8] Zymniaia, Y. A. (2020). Kompetentsyia y kompetentnost $v$ kontekste kompetentnostnoho podkhoda v obrazovanyy Elektronne dzherelo. http://www.rusreadorg.ru/ckeditor_ assets/attachments/63/i_a_zymnaya_competency_and_competence.pdf (01.02.2020). 
[9] Kalchenko, A.H. (1999). Osnovy lohistyky : navchalnyi posibnyk. Tovarystvo Znannia. KOO.

[10] The World Bank. (2018). International LPI. Global Rankings 2018 . https://lpi.worldbank.org/international/global/2018 (10.02.2020).

[11] Ovcharuk, O.L. (2003). Kompetentnosti yak kliuch do onovlennia zmistu osvity. [Competences as a key to updating the content of education] Stratehiia reformuvannia osvity v Ukraini: rekomendatsii z osvitnoi polityky.

[12] Pometun, O.I. (2004). Teoriia ta praktyka poslidovnoi realizatsii kompetentnisnoho pidkhodu v dosvidi zarubizhnykh krain. [Theory and practice of consistent implementation of the competent approach in the experience of foreign countries] Kompetentnisnyj pidkhid u suchasnij osviti: svitovyj dosvid ta ukrains' ki perspektyvy: biblioteka z osvitnoi polityky. K.:«KIS», S, 15-25.

[13] Ponomarenko O.A. (2006). Pidhotovka maibutnikh ofitseriv tylu Derzhavnoi prykordonnoi sluzhby Ukrainy do profesiinoi diialnosti: avtoref. dys. na zdobuttia nauk. stupenia kand. ped. nauk: spets. 13.00.04 "Teoriia i metodyka profesiinoi osvity. Khmelnytskyi.

[14] Verkhovna Rada Ukrainy. Pro vyshchu osvitu: zakon Ukrainy vid 1 lypnia 2014 roku № 1556-VII: Internet-portal. Elektronni dani. Kyiv: Verkhovna Rada Ukrainy 1994-2017. http://zakon3.rada.gov.ua/laws/show/1556-18 (17.12.2019).

[15] Ministerstvo infrastruktury UkRainy. (2020). Stratehiia staloi lohistyky ta Plan dii dlia Ukrainy. Proekt dlia rozghliadu. https://mtu.gov.ua/news/29401.html (01.01.2020).

[16] Taranenko, I.H., \& Yermakova, I.H. (2000). Rozvytok zhyttievoi kompetentnosti ta sotsial'noi intehratsii: dosvid Yevropejs' kykh krain [The development of vital competence and social inclusion: the experience of European countries]. Kroky do kompetentnosti ta intehratsii v suspil'stvi [Steps towards Competence and Integration into society]. Kyiv: Kontekst, 37-40.

[17] Khutorskoy, A.V. (2003). Klyuchevye kompetentsyy kak komponent lychnostnooryentyrovannoy paradyhmy obrazovanyya. [Key Competencies as a Component of the Personally Oriented Education Paradigm].

[18] Chyzhevskyi, V. (1996). Zahalnoievropeiskyi aspekt formuvannia zmistu osvity v kraini: mater. Vseukr. nauk.-prakt. konf. "Standarty zahalnoi serednoi osvity. Problemy, poshuky, perspektywy. 